原 著

\title{
Setsu OGAWA: On Some Problems of the Eugenics and Maternal Protection Law
}

\section{優生保護法の問題点について}

\author{
長野県須坂高等看護学院
}

小 川 節

去る1955年の 4 月, ニューヨークで流産を 主題とする会議の席上, 日本の人工娃娠中絶 が問題となつた。そのときロチェスターの産 婦人科助教授ポマレンケ博士が 日本の人工流 産の驚くべき状況を報告したのに対し，かね て日本の人口問題を分析して，事情を知つて いるプリンストン大学のアイリーン・トイバ 一博士が「日本の人工流産の漫延については 日本人が 人工流産の問題をキリスト教の神学 や信条の見地から評価する習慣もなく，また 大多数がキリスト教信者でない事実を忘れて はならない，従つて日本人流の考觉かたでは 産児制限が娃娠前に行われようが，後に行な われよ5が，道德的，宗教的飞も差はないの である」という意味の升護をして悬れられた という記事（資料1参照）をよ又筆者は国民 のひとりとして，この屈辱感は忍び難いもの があつた。

このよ5な人工流産の横行は昭年 27 年の 「優生保護法の」改正がもたらしたものと云兄 る. それは戦前の国民優生法の基盤の上飞昭 和 23 年 7 月修正を加兄て出来たものに，さら 新たな修正を行つたわけである。その要点は 母性保護であつた。 したがつてその概要は一 定条件を具備するケースに対し, 医師の認定 による（i）人工流産手術, および (ii) 受胎 調節ならびにその実施指導である。この法律
によつて，貧困の理由による人工娃娠中絶あ るいは受胎調節が公認されたことは, 日本の 母性史上永遠に残る記録的な出来事である。 5 .

この人工流産の社会的適応なるものは世界 の常識従つて慎重に取入れられたものであ る. 法の字句の上では, 産婦人科医に対し無 制限に人工中絶を許したわけではない。それ であるからこそ，この法律改正が国会を通過 したのである. 従つて人工流産手術の適応条 件が具倩されなければならないことは言をま たないところである。すなわち

「娃娠の継続または分婏が身体的又は経済的 理由により母体の健康を著しく害するお打て あるるの」あるいは

本人又は配偶者の悪質遺伝疾患の場合, 及 び本人又は配偶者の 4 親等以内の血族関係に ある者が 悪質遺伝疾患又は遺伝性奇形を有し ている場合，又は

暴行, 脅迫によつて抵抗, 拒絶することあ たわざる間に妍淫され妊娠した場合等 においてのみ認められるべきものであるが， この重大な理由の認定を医師の独断に任せて いるという現状の「法の運用」否, むしろ法 律そのものの不明瞭な箇所のために, 結果的 に中絶現象が跳梁する所となり，倫理道徳性 を失わしめ人間性の消退の風潮を誘導するに 
至つた感がある。一方また手術そのものに伴 ら直接の母体の危険执よび術後の障輩すなわ ら後䢖症等の保健学上の難点を思うが故に, ここに篚者は資料を整えて優生保護法を批判 し，本法の改正の促進を期するとともに，他 面一般の教育普及ならびに 医師に対する㗼法 精神の鼓舞を促し，今後願わくは正しい家族 計画に基づく「人間らしい生活」の理想実現 に多少の寄与を呈することを志す次第である。

\section{1. 受胎調節の起源と変遷}

〈総 説〉受胎調節は，一般には近代にな つて始まつたことのように受取られているが， 実は既に原始時代に，その萠芽があり，後次 第に行われていたのである.

（1）原始莀業民族に打いて，児の数を調節 しょうとする社会的，経斎的理的に基いて， すでに受胎調節が行なわれた。

（2）数の調節は，受胎調節に限らず，原始 社会に扣いては不必恶な子女の数を少なくし ようとする単純な欲求に重点が置かれて和り, 真の受胎調節に 対する女子の個人的要求や， その保健上の效果は秉角実現されることが少 なかつた。したがつて帟胎も殺児も受胎調節 の初期野輁時代の代替物であつた. 乙かし受 胎啁節そのものも古くから存在し, 原始野蛮 の状態を脱しょうとしている種族の間に存続 して来たのである. しかし受胎調節の実行は 恶胎や殺児に比して稀であつたばかりでなく， この時代の受胎調節の方法は，ほとんど魔術 的で効果にそしいのが特徵であつた。

（3）古代ギリシヤとローマでは多くの医学 者たちが，その医学体系の中に受胎調節を論 じている、乙かしそれも必ずしも学問的とは 吾い難い.

（4）近代以前の受胎調節の特色としては, その欲求の存在は, それぞれの社会の人口事 情の反映とは限らず，云わば共通の社会現象 として存在したものであつて，人口增加が歓 迎された社会や時代においてさえも認められ
たことである. しかし，その普及がどの程度 のものであつたかは判然としない，とにかく 人口現象を左右するほどの普及率であつたと は云壳ない。

（5）近代的受胎調節の特色は，19世紀後半 以降に扔いては，それが人口增加の支配的要 因とさえなるに至つた程の普及を遂げたこと である。乙かし，又その普及宣伝がひとつの 社会改良連動として組織化されるに及び，一 而では社会学的, 経済学的理論基礎を有つと ころとなつた。このような近代的特色は，形 式的には受胎調節の 組織的普及とその結果と してひとつの新しい社会的慣習の 形式である 受胎調節の「社会化」へと発達した.

（6）新マルサス主義の考光方が近代的な受 胎調節の特色であり，な扔かつ組織的な社会 改良運動の 基礎理論が 新マルサス主義の背景 をなしている。

（7）日本に括ける受胎調節の導入としては 戦前と戦後とに大別して見て行くのが邀当で ある.まず戦前大正 11 年，マーガレットサン ガー夫人の来朝を契機として「人道立䉝」主 張の段階となる. しかしこれとても世界の糜 史或いは社会赹勢がそのま〉反映され学值者 の生活水準の向上及び 贫困から逃れるための 自衛手段としてであり，又，婦人解放運動思 想へと推移を示すところとなつた。 しかるに 大正後期から昭和に至つて我国は「軍国主義 時代」に入り「国力盛衰は人口である」との 国策の弾圧の対象となり従つて人道主義主張 への考慮は払われずひたすら数的減少を和そ れるところとなるに及び本主義はその主張す ら認られないところとなる。

（8）第 2 次大戦終結後は「敗戦」により 46 \%といら狭小となつた国土，人口密度は世界 3 位を占めさらに外地からの引揚, 復只と 22 〜24 年にわたる「ベビーブーム」は恿々急激 な人口增として「国の収容力」に不均衡を来 したため，人口增を短期間に抑圧するのやむ なきに至るや，巷間でもたまたま受胎調節の 
言葉が「産児制限」と同一視した狭い解釈で 使用されるに及び一般国民には「産児制限」 の語のひびきから単純に制限と解されるとこ ろとなり，通俗的に「人工妊娠中絶」すなわ ち人工流産の流行を招き児の生命権は大人の 都合次第という状態を来たらしめるところと なつた. かかる「ヤミ」と称せられた人工妊 娠中絶の横行はやがて世諭を刺激し，その解 決策について諸論続出するところとなつたの であり，これに応えるものとして戦前の「国 民優生法」を母体とした「優生保護法」の成 立を久たのである（資料2），従つて本法は中 絶の監用を阻止することと，中絶手術を受け る場合の根拠，不妊手術の濫用阻止とそれを 受ける場合の根拋等要件を定めた.

このように古い歴史から迁余曲折しつつ時 代を反映し，また文化的所産として变㹂し来 つた受胎調節も，個人から組織化の段階へと 成るに及んで深く人間性の本得にまで触れる 重大な問題としての認識が要請されることと なりそ机は「家族計画思想」の㤵培から国民 運動に过䯩められることになつた。

〈受胎調節の歴史〉個々の男女がその個人 的必要に応じて出産を調節しょうという考古 方は, すでに数干年も前の古代社会に発生し ている.

（1）古代エジプトに於ては BC 1850 年頃 すでに近代的調節方法の萠第が認められ，文 献は技術の存在や程度を示すものであるが， 広い籁囲にわたる社会的慣行の存在を示して はいない。

（2）古代へブライに於ては産めよ殖えよ地 に満てょ, といつた頃から医学的, 社会的, 経済的事情に基く受胎調節の 手段と存在と実 践が認められる。

（3）古代ギリシヤとローマに於ては, 医学 体系の中で当問題が論議され, 中でも 2 世紀 の前半と 6 奾紀の前半に盛えとなり，19世紀 に至るまでに重要な遺産を残したものといわ れている、しかし宗教の絶対的支配下にあっ
た中世に和いて，教会はもとよりすべての産 児に対して反対の態度を明らかにした。

（4）近世及び近代に至るイギリスに於ては 近代的受胎調節運動の起る 19 世紀に至るまで 多くの通俗医学の文献によると，その手段は。 凡そ中世的な共通特色を有し, 受胎調節の慣 行についても中世と類似しているが，乙かじ 大きな発達の 動機は 1798 年 英国の 経済学者 （兼牧師）のマルサス提唱するところの人口論 である. マルサスは人口と土地の配合につい て食糧すなわち土地の生産とそれを消費する 人口との增加に見る不整合の関係を説いた。 （註マルサスの人口原理）

（5）新マルサス主義の形成として1821年英 人フランシス・プレスはマルサス主義の主張 に強い抵抗を示しつつも, それを承認しマル サス人口理論の正当性を認めつ〉，但しその 実行方法を改变したものである.

（6）アメリカに於いては人道主義的立場か らマーガレット・サンガー夫人, マリー・スト ープス夫人の協力を得て本運動が献身的にす すめられた。

（7）日本に於ける本運動は大正11年サンガ 一夫人の来日を契機として発展した。しかし 当時の日木に和けるこの方面の運動は世界の 塯勢が庈咉されて学働者の生活安定のため, 貧困家庭の 救出手段として期待がかけられて いた。

当時の日本の事情から, 出生制限を全面的 に経済の立場からのみに固執せず，学働者の 生活水準の向上と貧困からの解放という二点 をもつていたことは約 100 年前のマルサス主 義と共通するものを蔵しているといえよう。

大正後期から昭和初期に至る日本は軍国主 義時代に入り「出産制限（受胎調節）は国力 衰微の起因である」という国筑上の制約から弾 圧の対象となり「社会改良運動」の態度には 移れないままに逆コースを辿り，古代へブラ イのように多産主義を説いたのが，軍国政府 の「産めよ殖えよ」政策であつた。昭和 20 年 8 
月15日約 8 年間の戦闘に終止符がうたれ，敗 戦国と化した日本領土はすでに 国民を収容し きれなくなるに及び，余儀なく出生しょうと する胎児に，その人口增を抑圧する突破口を 向けたのである.

このときに人工妊娠中絶の 汇濫とそれに伴 5母体の健康障害，また人命軽視の念の㳂透 のおそれ等に対する緊急の処置として「優生 保護法」の成立をみるに至つたのである.

\section{2. 近代社会に於ける家族計画の意図と展開}

〈総 説〉近代社会に於ける家族計画の意 図は人間らしく意義ある生活を筑きたいとい 万欲求が基礎となつている。従つて人間らし い生活を築こ とする，その大前提となるも のは「家族計画思想」であり，それは個人， 社会の諸生活部面に広汎に関与する.

家族計画はいまや生活現象として生活の技 術であり国民生活に定着性をもつものである.

（1）小家族主義の風湖は家族を計画的に構 成しょうという夫陆の责任むる家庭経堂の因 子として生活設計の中枢的存在として関心事 となる。

（2）人間も動物である. しかして他の動物 同様に自分の生命の存続と種族繁殖の 性生活 とを営む。

しかも人間は考党る動物である.すなわち 考える能力を駆使して人間の生活条件を向上 させようとする。

（3）家族計画は世界的に滲透し文化の程度 や形態によつてその支持論議は個々異色もあ ろらが，先進国に於てはすでに人口問題から 脱して, 母子保健, 家庭の幸福の域に展開す るところとなつたのである.

〈家族計画思想〉人間は考古る能力を駆使 して人間の生活条件を向上させようと努力す る. したがつて人間の歴史は自己の生活向上 に大河のような努力の歴史を創つていく， し かるに生活条件は一挙にしては得られない。 それは，技術，生産，政治等の制約，更に人
間自体の能力からの制約からも同じことがい えるのである、従つてそれらの環境条件を打 破しようとする努力を行ない，同時にまた現 実の条件に適応させよ5と考究していくので ある。

(1) 家族の構成は人間にとつて必然的な生 きる表現でありこれについても当然，人は環 境適応を考虑する。これが家族計画思想であ る.したがつてこの思想の発生は「生きる」 が基礎となり「よりょく生きょう」と願うこ との認識から出発する生き方の条件に対する 認識が元になる。

（2）生活への櫬識と向上への欲求が外に向 うと同時に内省に訴える。これが必然的に家 族構成を考虑しようとする動因となり従つて， 家族計画が世界に於ても文明国に普及定着 し，一国に和いても比較的文化に恵まれた階 層に普及し 漸次下降するのはこの間の事情を 説明しているものとおもう。

〈概念の規定〉計画出産には成功した。乙 か乙家庭生活は充实しない。これでは本末䫟 倒である. 従つて以上の意味からいつて明ら かであると括も5が，家族計画の実際では子 供の数に関し政府が 命令的態度をとることは 避けなければならないし，又不妊症の問題も 同時に取扱われなければならない。

（1）子供はすべて望まれた子として出産し 人間が誕生して一生を送るときに社会的，精 神的，物質的にも幸福で人間らしい生活ので きるように願うのであって，生活内容の理想 実現を図りつつ生さることにその意義がある のである.（註昭和 36 年度日本家族計画普及会 編「家族計画便覧 p.3」)

(2)「家族計画」と「計画出産」との二つ が，前項理論に立脚して，最近好んで用いら れる熟語である。「家族計画」の語は英語の family planning に対応しており「計画出産」 は, planned parenthood に対応する. 家族 計画とは「欲しいだけの子をほしい時に産む」 と説明している。しかし，また「子供はすべ 
て望まれた子として産む」ことであるとも説 明されている.

特に家族計画と 銘打つて使用された場合に は, 子供の数, 出産の時期, 間隔というよう に具体的な現象だけを指してはいけないので あつて，それは家族思想そのものであると思 5 .

（3）受胎調節の定義は受胎を人為的に調節 するために必要な医学的技術ということであ り，家族計画をしようとするにのぞんで妊娠 の調節を図ることである、現在受胎調節とい つて実際は家族計画を意味している。しかし 本来は，産みたくない，或いはときによつて は如何なる方法で如何なる時期に 産んだらよ いか，ということで，それには人間の生理, 薬品, 器具等の他に技術的な知識を如何にし て取得できるか，といら意味の言葉である。 従つて政府や団体が行なら一般啓蒙普及事業 は，家族計画普及事業であり実施に細密な技 術のみを教える場合は「受胎調節堾施指導員」 が担当する.しかし一般的には受胎調節と， 妊娠予防という意味だけに限つて使用されて いる場合が多い。

〈家族計画の現状〉戦前でも勿諭, 日本に は避妊はむる程度普及していた。毎日新閆人 口問題調查会の調查推察によれば（昭和 11 年 末）約 6\%が実行していた。乙かし避妊への 爆発的欲求が起つたのは勿論第二次世界大戦 の経済混乱，生活窮乏期においてである.

ひとびとは出生抑制を自己保全策とした。 従つて受胎調節の技術も普及しないときなの で, 産児制限への欲求は人工妊娠中絶への強 い欲求となり，「ヤミ中絶」が横行し母体の障 害は頻発しこれを合法化するための「優生保護 法」が成立してからは，更に急增していつた。 この膨脹しきつた人工妊娠 中絶を如何に「家 族計画」の本質にかなつた受胎調節にきりか えてゆくかというところに課題が宿されてい る。

\section{3. 優生保護法実施に伴う様態}

〈総 説〉. 家族計画の現状は, その運動に より可成りの思想を啓培しつつあるところで あるが他面末だ少なからず動摇をつづけてい るところは甚だ覔虑に梖觉ないところである。 その表れとして，産児制限の意味のとりちが いと見做すべき人工妊娠中絶，優生手術は依 然として跳梁を極めているところである.

昭和 23 年 7 月 13 日法第156条を以つて成立し た「優生保護法 実施以来十数年 経過した現 在に至るも, 中絶の数は年間凡そ200万件に及 びその結果母体の障害も相当数にのぼり， 24 年より約 8 年後の 31 年に行われた優生手術は 213955 件の警異的数である. しかしそれらの 防止ならびに解決策はひと元に家族計画運動 の教育面にのみ委ねられている現状である. この戦肃なる事実に法は如何なる措置を執つ ているのであろらか。この事実は各々都道府 県の出先機関である保健所機能の部分的麻痺 の表れでもあると思うのである。なぜならば 「優生結婚相談所」の看板は「開店休業」状態 であり PR すら行われていないというのが実 態である。これでは迷える子羊は誰にすがつ たらよいのか，こらなると厚生省の筋のと拉 つた方針が望まれるところである。

（1）優生保護法の功としていえることは (a) 強いていえば法実施後年間平均凡そ 3000 万，をた優生和術を受けた者が 1 人の生 産を抑觉たと推定しても 213,955 件，この合 計は $26,213,955$ 件の人口を抑圧したことにな り一応人口増加が抑えられたことである.

(b) 非嫡出子の出生防止とい5点に掠いて は大正 9 年当時 $4 \%$ の出生をみた 非嫡出子は 昭和 33 年には $1.4 \% ， 34$ 年にいたると $1.3 \%$ と 下降して括り，社会的，個人的諸事情からの 出生抑制 (胎児の生命侵害) が 非嫡出子の出 生にも強く作用しやすいとい5一般論を裏づ けている. しかし一応は法益の功と解されて いるのではないだろうか。

（2）法の罪と和もわれるものを指して，最 
善をつくした如何なる法を以つてしても，当 然矛盾は相当に存在するのを避け難いとみる むきもあるが，その益の少きは無法に等しく なるものではないだろらか.

（a）人工妊娠中絶手術は，優生保護法を軽 視しているものである. 中絶手術汇濫が母体 の健康と生命を極度に阻ばみ，ややもすると 慢性自殺的状態に拈としいれていることを手 術者中幾人が菬虑するものだろらか（この周 辺のことがらについては中絶体験の記を照合 することとする，後のページにゆずる）

（b）法の運用はあまりにも軽率に扱われ て，その乱用は「侲生手術の名目で不妊手術 を横行せしめ， あるいは緊急非難措置などと 詭弁を弄しているところは，法の軽視，無視 以外のなにものでもない。

（c）安易に行える中絶手術の悪習は性道徳 をも動摇せしめ人倫まことに夏うべき問題で あるといわねばならない，従つてこれらの詳 細怯各節を避つて考察することとする。

\section{〈死産統計の分析〉}

（1）䀔和澌に入つてからの人口動態

昭利 1 年以降 22 年までは不䛠であるので23 年 7 月法策施後の13年間を対象とする.

(a) 自然死产率は23年の36.6\%であつたも のが35贸に至りては $52.3 \%$ とピークを示す.

（b）人工死産染は 30 年から 32 年をピークと 乙雨来下降線を辿り 34 年には $49.3 \% ， 35$ 年に は $48.2 \%$ と安定の傾向にある.乙かし23年の 10.9\%から 30年迄の上昇線は 40.4の較差を生 じ，自然死産のそれに比し約2.5倍強となつて いる。な拈自然死産の因子として人工妊娠中 紿による障䩀が作用しているものと拈もわれ る.この原因は概ね人工妊娠中絶, 人工死産 等が動因となつて妊容力を低下せしめている ものと推定されるのである。

(2) 出生順位別死産比の分析

(a) 出生順位別に死産比を分析すると，自 然，人工ともに符 1 児に压倒的に多く符 2 児 における割合は低く，爾後児数を增すごとに
表 1 自然・人工別妊娠中絶数之死産率 (出生 1000 対年次推移)（資料 3)

\begin{tabular}{|c|c|c|c|c|c|c|}
\hline 棇数 & 総 & 数 & 自然死 & 産 & 人工死 & 産 \\
\hline 牛次 & 友 数 & 率 & 奜声 数 & 率 & 奏 数 & 率 \\
\hline S. 10 & & 50.1 & & & & \\
\hline S. 22 & 123, & 44.2 & & & & \\
\hline S. 23 & 143,963 & 50.9 & 104,325 & 36.6 & 31,055 & 10.9 \\
\hline S. 24 & 192,677 & 66.7 & 114,161 & 39.1 & 75,585 & 25.9 \\
\hline S. 25 & 216,974 & 84.9 & 106,594 & 41.7 & 110,380 & 43.2 \\
\hline S. 26 & 217,231 & 92.2 & 101,237 & 43.0 & 115,994 & 49.3 \\
\hline S. 27 & 203,824 & 92.3 & 94,508 & 42.8 & 109,316 & 49.5 \\
\hline S. 28 & 193,274 & 93.8 & 89,751 & 43.5 & 103,523 & 50.2 \\
\hline S. 29 & 187,119 & 95.6 & 87,201 & 44.6 & 99,918 & 51.1 \\
\hline S. 30 & 183,265 & 95.8 & 85,159 & 44.5 & 98,106 & 51.3 \\
\hline S. 31 & 179,007 & 97.1 & 86,558 & 46.9 & 92,449 & 50.3 \\
\hline S. 32 & 176,353 & 101.2 & 86,895 & 49.9 & 89,458 & 51.3 \\
\hline S. 33 & 185,148 & 100.7 & 92,282 & 50.2 & 92,866 & 50.5 \\
\hline S. 34 & 181,893 & 100.6 & 92,685 & 51.3 & 89,205 & 49.3 \\
\hline S. 35 & 179,193 & 100.5 & 93,287 & 52.3 & 85,825 & 48.2 \\
\hline
\end{tabular}

その比は上昇している.

（b）第 1児出生に対し 自然死座比は $60 \%$ 人工死座比は $52.7 \%$ いずれも半数以上は出生 をさけている.

(c) 符 2 児出生に対しその自然死産は，45 $\%$ 人工死産は $26.7 \%$ となりここにおいて第 1 児の出生は極力さけ，第 2 児の出生を迎えて いる。

(d) 第 3 児出生に対しその自然死産は53.6 $\%$ 人工死産は $45.4 \%$ で 3 人の子は荃えないと いう表意となるようである。

（e）第 4 児の出生に対し自然死産は $72.3 \%$ 人工死産は更に高く $101 \%$ と殆んぞ欲しない妊 娠であつたことを意味する。

(f) 符 5 児に至りては自座死産 $83 \%$ 人工死 商162.5\%となる。

（g）第 6 児以上は大部分が惰性による妊娠 と中紌の反復であり， $97.3 \%$ の自然死座，人 工死㦃は $216 \%$ となりこのよ5にして第10児に 问らに従つて胎児の生命権はいたずらにまこ とに身勝手な者達のためにほうむり去られて 
表 2 出生順別にみた中絶数と死産比

（資料 3)

\begin{tabular}{|c|c|c|c|c|c|c|}
\hline \multirow{2}{*}{\multicolumn{2}{|c|}{$\begin{array}{l}\text { 死産数- } \\
\text { 内訳 } \\
\text { 出生 } \\
\text { 数 - 児数 }\end{array}$}} & \multirow{2}{*}{ 出生 数 } & \multicolumn{2}{|c|}{ 死 産 数 } & \multicolumn{2}{|c|}{ 死 産 率 } \\
\hline & & & 自然 & 人工 & 自然 & 人工 \\
\hline 総 & 数 & $1,626,088$ & 92,688 & 89,205 & 57.0 & 54.9 \\
\hline 1 & 児 & 681,795 & 40,865 & 35,931 & 60.0 & 52.7 \\
\hline 2 & 児 & 506,336 & 22,792 & 13,498 & 45.0 & 26.7 \\
\hline 3 & 児 & 242,812 & 13,014 & 11,024 & 53.6 & 45.4 \\
\hline 4 & 児 & 102,338 & 7,402 & 10,334 & 72.3 & 101.0 \\
\hline 5 & 児 & 48,770 & 4,050 & 7,925 & 83.0 & 162.5 \\
\hline 6 & 児 & 23,422 & 2,278 & 5,060 & 97.3 & 216.0 \\
\hline 7 & 児 & 11,188 & 1,142 & 2,827 & 102.1 & 252.7 \\
\hline 8 & 児 & 5,227 & 553 & 1,424 & 105.8 & 272.4 \\
\hline 9 & 児 & 2,293 & 322 & $691 \|$ & 140.4 & 301.4 \\
\hline 10 & 児 & 1,893 & 2.15 & 491 & 113.6 & 259.4 \\
\hline 不 & 詳 & 14 & 55 & - & & - \\
\hline
\end{tabular}

いるのである.

（3）原因別死産とその割合，圧倒的に多い のが胎児側の原因として $59.9 \%$ ，続いて胎盤 異常, 難应であり, 人口死産の圧倒的に多い のは「妊娠及び出座の疾患之異常」であり, これは法第14条 4 項該当事項に 当該するが し かし真疑のほどは尚今後も検討の必要がある とおもう。

\section{〈人工妊娠中絶の現状〉}

前節に打ける人工死産も，本節に和ける人 工妊娠中絶も，人為的に妊娠継続を中断する 行為である.

（1）人工死産と人工妊娠中絶

（a）人工死産と自然死産を問わず妊娠 28 週 からは事件発生の場合の手続方法が 定められ ているにもかかわらず実際にはそれほど正し くは行なわれていない。

（b）人工妊娠中絶中流産手術は（上の（a） 以前に該当） 3 ケ月以内の胎児（母体外にて は生命存続かなわざりし時期) が要件のひと つとなつている. 従つて (a) (b) の術式も異 つてくる.

（2）昭和 24 年総数において 246,104 件， 25 年 489,111 件と約 2 倍の 急増を示しているが
表 3 昭和 34 年原因別死産とその割合

（資料 3)

\begin{tabular}{|c|c|c|c|c|}
\hline 死産比 $\cdot$ 種別数 & 死 & 数 & 百 & 比 \\
\hline 総数 - 死因 & 自然 & 人工 & 自然 & 人工 \\
\hline
\end{tabular}

総 数 $65,568|89,120||100.0| 100.0$

目体の慢性疾患 $57224,450 \quad 0.927 .4$

母体の急性疾患

奸娠及び出産の疾患

及び 異常

母体よりの毒性物貎

の 吸 収

難産

その他の母体侧 因

胎盤及び臍帯の異常

出産障害

胎児の先 天性 奇 形

胎児の疾病及び

䛦断名不適のもの

$\begin{array}{ll}0.6 & 0.2\end{array}$

$5.6 \quad 65.0$

$0.0 \quad 0.0$

$11.3 \quad 1.3$

\begin{tabular}{l|l}
6.7 & 1.9
\end{tabular}

$12.2 \quad 1.7$

$\begin{array}{lll}1.1 & 0.2\end{array}$

$\begin{array}{lll}1.5 & 0.1\end{array}$

59.9

2.1

中絶月数は不明となつている. 他の年次をお つていくと, 当初の 26 年に 3 月以内の受術者

は 80.8\%であつたものが，35年になると 93.0 $\%$ 月以内の中絶者が巾を広げていて，こ の点は趣旨が渗透してきたものと推定される ところである。しかし他面施術医師は知事の 指定を受けた者でなければ行うことは許され ないことになつている。

表 6 にみるよ5に（a）20才代に稍々低く 爾後年令の進むに従つて上型線を示し表 2 の 出生順別死産の分析と同一傾向を示している ことに注目しなければならない，35才以上と なると全く妊娠の都度中絶している 結果をう かがうことができる。 また同一人の数回反復 受術が推定される.

上記表 6 をみると術後に診断名は名目上に おいてつけられている感じをいだかしめ,さら にまた「母体保護」に関する医師単独の認定 を要するものより以上に「経済的理由」の圧 倒的多数は今後に㧍ける大きな課題ではない だろうか。

優生保護法第 3 章 14 条 4 項に 根拠をもたせ 
数の分析

（a）中絶回数は初回でも障害は起り得る. 従つて反復により一層その可能性は強度とな つている.

（b）その主なものは, 頭痛, 発熱, 出血, その他として場合によつては再妊娠を促し，ま た逆に不妊症あるいは慢性自殺的障害等々直 接間接影響が大きいと和もら。

（5）全中絶件数に対する障害の比

人工妊娠中絶による障害発生の 種目別調査 によると 総数 5209 例につき（a）出血長期持 続したもの $5.1 \%$ (b) 腹痛を伴つたもの 2.7 \% (c) 出血多量であつたもの $1.6 \%$ (d) 発 熱したもの $1.5 \%$ （e）その他の障害を起し たもの 0.5\% となりその他としての内訳は, 内容残留, 子宮穿孔, 附属器炎, 頸管裂傷等, 以上に久る障害は，中絶手術を行なわなけれ ば当然和こらなかつたことでありまことに 医師も患者も生命に対しての慎重さが望まれ るところである.

\section{〈届出優生手術の現状〉}

まず法の条文を引用する。

1. 医師の認定による優生手術

第 3 条, 医師は左の（下記）各号の 1 亿該 当するものに対して本人の同意並びに配偶 者の（届出をしないが事奏上婚姻関係と同 様な事情にある者を含む以下同じ）あると きはその同意を得て，優生手術を行なうこ とができる。但し未成年者, 精神病者又は 精薄者については，この限りでない。と定 められた者の優生手術を認めている.

（1）本人若しくは配偶者が遺伝性精神病 質，遺伝性身体疾患若しくは精神薄弱を有 しているもの.

（2）本人又は配偶者の 4 親等以内の血族 関係にある者が遺伝性精神病, 遺伝性精神 薄弱, 遺伝性精神病質, 遺伝性身体疾患又は 遗伝性奇形を有しているもの.

（3）本人又は配偶者が瀨疾患に罹り，且 つ子孫にこれが伝染する惧れあるもの.
（4）妊娠分婏が母体の生命に危険を及ぼ す惧れのあるもの.

（5）現に数人の子を有し且つ分婏ごとに 母体の健康度を著しく低下する惧れのある もの. と定められている. ここに現状の傾 向を表によつてみることとする.

2. 審査を要件とする優生手術の申請

第 4 条，医師は，診断の結果別表に揭げ る疾患に䍜つていることを確認した場合に は，そのものに対してその疾患の遗伝を防 止するために優生手術を行ならことが公益 上必要であると認めるときは，都道府紧優 生保護審査会に優生手術を行うことの適否 に関する審査を申請しなければならない。

(1) 優生手術の契際は第 3 条によるものが 極めて多く，なかでも符 4 項該当を理由づけ ているのであって 全優生手術中 $96 \%$ 占てい る.

（a）昭和 24 年以来 31 年迄の 8 年間の経過を みると，遂年上昇線を示し最近に至るもその 傾向は衰退していない（届出数に対し実際に は 5 倍以上と推定されるむきもある).

（b）受術者の年令分布をみるとやはり永久 的不妊手術であるため 20 才に少く 30 才を越え る頃から 40 才に至りてピークを示している. しかし不妊手術が決定的手段であるとして， 安易に考えた場合全く本法の精神はゆがめら れてしまつて「優生」を意とする思想はみじ んも必要とされなくなつていくのではないだ ろらか.

（2）長野県に於けるこの実態を参考迄に載 せてみよう。

昭和 24 年から 35 年に 至る12年間の 経過中の 㬰施数は6824件である.

（3） 24 年中受術者令 2 ㅇ 102計 104,35 年に 至り令 16 우 631 件, 総数に特いて令 295 件 우 6529件その計 6824 件.

(a) 第 4 条は審査を要件とするものでは県 予算にみられるものとしては大体年間 30 件程 度としている。現に著者も市町村勤務中この 
ようなケイスに関しては少なからず皮肉な関 係をも見ている. それは別表 $1 ， 2 ， 3$ 亿該当 する取扱上審查会に, 市町村長の請願書添附, 或いは知り合いの係に喰い下って，漸やく認 可の段取りとなつたものの， 戸籍書類，実情 調査にと係官同道で現地に打もむきそれは単 なる公費手術の 希望によるもので，しかもケ イスの身体及び生活の惨たる現状を知り, 救 出できえたことがあつた。

費用が個人か公費かというただとれだけで 簡単，厳重に処理してよいものではないと抒 も5.ここにも今後の大きな問題点があると 扣もらのである、法の規範性を軽視する悪習 防止, 除去, 人間性軽視の念とモラルの在り 方等が問題だからである.

\section{4 優生保護法を分析する}

〈総 説〉年間 200 万件に及ぶ人工妊娠中 絶，届出された䨤生手術は凡そ 42840 件（実 際には20万から40万と推定される）の高率を 示し，またそれに伴う諸種の障害は限界を極 めている。この事態は法をもまた道徳性をも 全く逸脱しているものであり，これを長年月 に亘つて認容することは，大きな社会悪を招 き，「優生」は全く道化師にすぎさるを得な いと怙もわれるので前ページには本法の運用 とその技術ならびに，規範性の存在がなへん に在るかを様態的に 書いてきたがこの章にお いては跳梁する中絶魔，乱用される優生手術 等によつてこ扣むる幾多の障害を防止し憲性 の保障する公笔衛生思想を揚め, 健康なから だで文化生活を営むことへの意義を新たにす ると同時に法理念が 正しく実現されることが 要務であると信ずる次第である.

〈優生保護法には疑問がある〉年間 200 万 件に及ぶ人工妊娠中絶，或いは20万ないし40 万件に界る僄生手術の横行また 氾濫をどのよ うにみるか。

（1）一応根拠としては法第25条（届出）に 基いて「医師又は指定医師は人工妊娠中絶又 は優生手術を行なつた場合にはその月中の手
術の結果をとりまとめて翌月迄に，理由を記 して都道府県知事に 届出なければならない」 と定められている(月報報告)、又第32条に拈 いては「第25条の規定に暹反して 届出をせず 又は虚偽の届出をしたものは，これを 1 万円 以下の買金に処する」と定めている. しかし 実際には誰れがどのようにしてその違反及び 「虚偽」の届出を正すのであろらか。ちなみに 刑法に於ては「被害者」からの届出, 或は申 告を以て法の保護を求めるところであるが， 本事件の場合，被害者はプライベイト或いは プライバシーに触れられることを嫌らという 心理作用が極度に働くため認識しているもの でもいわゆる泣きねいりに終るか又は全くそ 対処の方法すらしる人は多くないと拈もう。

又医師会が会員の失敗，落度を告発すると いうことは実際の場合，会員相互の業務道徳 を堅持しなければならないといら社会的背景 を考虑してしまうという点から，不可能であ ろ5. 従つて本件についての進法性に対し疑 問視は可能であつても問いただすということ は打打むね不可能にちかいとみるべきではな いだろらか。

表 6 に示した神奈川県に拊ける実態調查資 料にみられると打り,完全に第23条に適応する と扣も5のであるが事態は至極安泰に済まさ れているという．従つてこれも刑法第156条 （虚偽の公文書作成）に違反したる者は 1 年以 上10年以下の嶶役， 3 年又は 300 円以下の曙 金に処すと定められてありはしても準用規定 は医師法にない。従つてかかる事件は殆んど が迷宮入りとなつている。

（2）法の字句には無制限に白紙委任をして いる感をいだかせる。

法文上では産㛔人科医にフリーハンドが与 えられてはいないであればこそ法案は国会を 满場一致で通過したのであり「優生保濩法符 14 条 4 項」該当に限り人工流産手術を医師 は行なえることになつている. しかしこれら の字句に疑問をいだくのである，たとえば経 
済的理由とか，著しい健康障害とかいうが， 経済的理由を如何にして医師が認定でき得る かといらことで，これは福祉事務所の審査を またなければ判定でき得ないことであり従つ て医師が単独で経済的理由を根抛要件として 施術をなし得べきものではないと拈もう，又 「母体の著しい健康障害」というその著しさで あるが，これとても如何なるていどになれば 著しくなるのか，という基準がない。この条 件も実際のところ認定の「きめて」とはなら ない。このような場合法律では概念規定をす るのが当為であり施行規則によつて厳密な執 行を指導するものであると扔もう。例总ば学 働基準法の条文とその詳細な概念規定を定め ている施行規則に 安全規則の 数百条があげら れている. しかるに優生保護法の施行令も, 施行規則子貧困の認定や，健康状況について 何等の規定をも見当らないから結果的には 「指定医は如何なる場合にも人工流産手術, 隻 生手術ともに行ならことができる」のと混同 して意識される結果論に 終始してしまらので ある.

（3）口チエスター大学産婦人科教授のポマ レンケ博士は「手術の決定に関与する人間はそ の女性と，医師と，胎児とである」といって いるとうであるが，医師は人間でありまた， すべての医師がシュバイッァーになつている のではないといらことも社会通念である.

（4）次に己むことを得ざるといらことにつ いては, 生命に対する現在の危険又は，近い 将来の時期に 生命の危険を萑起するような極 めて重大な健康上の障害が 現在存在する場合 でもそのことだけではまだ中絶て対する刑法 上の責任が免れることにはならないと扔もう． 従つて「己むことを得ざる手段であつたとい 5要件が更飞必要とされているのである.」己 むことを得ざるといらことはとの「手段」に よるより他に手段がなかつたという唯一性の 意味であって， 母親の生命を助けるために， 母親の重大な健康上の障害を死の危険導か
しめないためには「中絶」といら「手段以外 に方法がなかつた」といらことが必要とされ ているのある. 従って他飞治療, 或いは予防 の方法がありながら単純な治療手段として中 絶にはしることは唯一性の要件を満さないこ とになる。しかしいかなる症状に対して人工 妊娠中絶が唯一の治療手段として許されるか は，その時々の医学が決定するものである. 乙かるに事実は第 3 章 3 節の 届出の名目と実 際のカルテ記載録の䛦断名相違に現われてい るが如きものがあることで，あるものなどに いたつては全く健康者への中絶は葄胎行為に ほかならない：この全く健康者の人工妊娠中 絶手術を刑法にてらすならば第 24 条（業務上 の随胎罪）の規定に反するものと思うのであ るが，この規定は何等準用されたといらこと をきいていないのである.

〈人工妊娠中絶をごのようにみるか〉すで に上飞提起した如く 1 度の体験儿て子障害発 生を招き，䫁回に至る程との度は高度となつ ている.しかしこれらの障害も技術の㯪劣性， 受術者の拱生, 環境等により障害の程度に種 々影響の起ることが考党られるが, いら゙れに せ上業務上飞発生せしめた偟害については明 かに傷害の罪であると扔もう．しかしこの点 飞拈いて子格別法はふれていない。

（1）医師法第 23 条（医師 業務上の注意義 務) が課されている. 従つて中絶手術の場合, 手術終了後, 本人又はその保護者に対して, 療養補導 その他保健の向上飞必要な事項の指 導即ち，爾後指導をなさなければならないと いう意味のことを規定している。 しかし実際 には上述に提起した如く中絶回数の增加に比 例して障害頻度も広くなつていることからし ても，医師法の第23条は徹底性に欠ける面を 表わしているところである.ここでいう爾後 指導とは，正しい理由によつて中絶手術を行 なつた場合「受胎調節指導」を為し以つて雨 中絶を予防しつつ母体の健康保持增進を図る ものである. 
（2）扣そるべきは人工妊娠中絶による障害 である。従つてこのよ5な事態も，中絶をす ることによつてのみ 発生を促がすといら特犋 を有する子宮穿孔，覀性じう毛膜上皮腫によ る死亡 $2.0 \%$ (発生\%は $2.6 \%$ ) と高率死亡を 発生している.

（a）刑法 204 条（傷害罪）優生34（違法優 生手術）本項準用

(b) 刑法 205 条（㑺害致死罪）裂生34（違 法優生手術）本項準用. 以上のよ5飞準用規 定がありはするけれども実際にはそれらの処 置はとられていなかつたと拈も5。

つい最近サリドマイド螎によるエンゼル心゙ イビーの誕生は妊婦に対しても未来の生産層 に向つても大きなショックをあたえたことで あるが，ある夫婹は孜奇的心理状態からか，そ の好奇心を満足させるため，妊娠初期のサリ ドマイド実験を試みて準倩を整え，更に医師 に依頼して生命を中絶された児を吾が目と指 で実験成縝を探ぐるという変態を示して一 般を慄然とさせたものであるが，あるいは一 般にはすでに中絶手術は日常の茶飯事として 処理してゆくひとつの 悪習慣が徹底してしま つているので，「世間の人がふつうにしている こと」ぐらいに考兄られているのではないた ろらか. 全くもつて人命尊重の思想を強化し なければならないことを消感させられるとこ ろである。

（3）人工妊娠中絶の被害例の分析

件例の記録は 非科学術雑誌の 記載に拠つた が，笵者の意図は，その記載を全面的に信用 することを前提とせず，記载の様な事故が起 る場合の問題点を分析して，各件例の性格を 理解するための方法論に 注意を向けようとし たものである.

[件例]八王子市 33 才の主㖊, (資料 7 参 照)

"中絶手術によつて私のからだは破壊した・ル 24才の12月初めて中絶を受けた. 当時 1 才を 迎えたばかりの長女の保奇を重視していたの
で，2度目の妊娠を犠牲にして手術を受けた。 しかし家庭の事情から手術直後すでに 儌かね ばならなかつた。そのためか, 下腹痛, 出血, に苦しみ遂に起きあがれない病人と化してし まつたのである。その烈しい症状も5日程で 止つたので，恢復したものと思いこみ健康時 同様の生活に 㞍つたのであるが 数ケ月後再び 妊娠徵候を感じ，迷5気もなく再び中絶手術 を受けたところ，またも出血，今度は 1 ケ月 以上も治療を続けたが 不正出血は依然として 続き，このころから極度に健康障害を感じ， 季節的にみても10月ともなると真冬の服, 真 冬の寝具，これでも保温にならず，室温が 14 ${ }^{\circ} \mathrm{C}$ から $15^{\circ} \mathrm{C}$ ていどになると，炬達から離 れることができない上更に年中カイロ包布を 抱き，〈つ下 3 足も重齐ばき，脱力感，顽消， 分泌物，と今は「撥疾者」と化して中紿への 悔恨に「生きる」希望を全く失い，劣等感情 だけが強くなりそれでも死ぬこと以外の帣え はもてなくなつてしまつた.

[件例 B] 新潟県の28才の主㛽（資料 7 参 照）

"子宮穿孔に苦し夕後遺症に恼む”

恋愛コースにおいて「妊娠」という事実に 警倒のあまり小さな産院に 馸けこみ女医の手 馴れた手術を受け経過も順調であつたため誰 にも気づかれずに勤めも続けていたところ羽 月再妊娠, 遂に 3 ケ月も過ぎてしまい結局最 初の女医の門をくぐつた。結果はよかつた. 乙かし再三の妊娠で遂に女医の門もくぐりに くくなり，隣目に行き処理しようと汽車にゆ られているらちに烈しい腹痛に吐気さえ加わ り遂に目的地より 5 つ手前の駅で下車，待合 室にらつくまつて痛みをこらえていると，中 年婦人が歩みより尋称られるがま〉に打明け ると, あるうらぶれた感じの医院へ案内してく れた。待つこと久しく突然にけたたましい悲 鳴がきこえ同時に30才位の婦人が這5よ5に して手術台から降りてその場にどつと横たわ つてしまつた。それをカーテンのすきまから 
みた私は全身に戦慄を感じ，逃げ出そうと抒 もつている矢先に呼ばれてしまい手術台に界 つた。 その間に何度もマスイを頼んだが受け つけられず，終了後は出血と痛みに 2 日入院 していたが一向に恢方に向わず，又何等手当 もしてもらえず心細くなつたので転医するこ とに決め会計をして二度びつくり，請求書は 12,000 円也となつていた．その後転医した医 師は早速診療してくれたが，「これはひどい。 よく今迄がまんができたものだ」と半ば呆れ 気味に「子宮穿孔」ですよと説明してくれた. その日から10日入院し軽恢退院，間もなく結 婚した。而しとれ以来 8 年すっかり不妊症化 した私は嘢哭と絶望感から生ける屍として暗 い日を送つている。

[件例 C]“未婚女性の中絶による子宮穿 孔”(資料 8 参照)

妊娠 4 ケ月の未婚女性, 日日育ちゆく胎児 の始末に独り悩み，家人にも告げず外出し小 医院にて中絶手術をうけたところ，愦つて子 宮穿孔を起し，大出血にあわてて，市立のある 病院へと転医, 救急処置により一命はとりとめ ることができた.ここまで家人の誰 1 人として 知るものがなかつた。遇々病院からの報を受 けて駐けつけた未婚の姉が 主治医から経過を きかされて一大ショックをうけた模様である。

「医師の説明によると妹は妊娠 4 ケ月，それ を撰把による流産手術を行なつたため軟い子 宮壁を穿孔し大出血から頻死の状態に括ちい り救急処置により生命はとりとめた」という 次第である.として文の末尾に，「家人にも連 絡なしで，勝手に未婚女性の中絶をした医師 の軽卒さを弓ら反ます」とめんめんと㻎かれ たにくしみの手記はすさまじいものであつた。 (家族計画ニュース10月号)

以上のよ5に類似ケースは多々記録されて いるが省略することとした。

A. B. C 3 例ともに（i）本人は知識が低い (ii) 家人も少々無関心, (iii) 医師も機械化さ れた職業人であつて 3 者とも非難に值するが,
特に，私は医師であればこそ守らなければな らない職業倫理の自临が余りにも薄いことを 嗼く.このためには現状のますに放置するこ とはできない。

今後の課題として

1. 法の改正

2. 監督管庁の責任むる態度

3. 医師自らの倫理と責任の再認識

4. 優生結婚相談所或いはマリッジカウンセ ラーの設置及び增員

5. 実施指導員の職業調整

6. 保健所と産婦人科医とのマザースクール についての在り方の調整等について考学 てゆかなければならないことだと思う。

\section{総 括}

戦前の国民優生法は民族の資質の優秀性を 確保する施策の一䍗として, 日本民族衛生協会 の多年に亘る熱心な唱導の線に沿い, 政府提出 として成立を見たものであり，との内容には人 工妊娠中絶の社会的適応を含几でいなかつた。

しかるに戦後，これを改正して，優生保護 法とし，さらに昭和 27 年の改正を綠た現行法 は，筫困の理由による人工妊娠中絶を公認す るに至つた。すなわち法文を引用すれば

「妊娠の継続または分娩が身体的または経済 的理由により母体の健康を著しく害する和と れのあるもの」

について人工妊娠中絶手術を容認し, 堕胎 罪に問わないこととなつた。これは監用され た場合には，抢そるべき害毒を流す拈それが あるが，法規としては一応の 対抗策が考えら れていた。しかし，その後の実施の実状は， まことに夏うべきものがある。

著者は保健婦の立場から，この際，本問題 の全容を概推して記録にとどめておくことに 意義を認めたので本稿を章した。

世界史上，受胎調節思想の起源は古代にさ かのぼるが，それが社会思潮の中に確かな地 歩を占めるに至つたのはマルサス以後のこと 
である、現在，日本を含めて怈界の文明国に おいて一般に行なわれている帣古方は，胎児 の生命の尊敩を尊重することと，社会に括け る家庭人の快適生活を確保することとの二つ を如何にかてて両立させたいというにある。

日本の場合には，大正期に入るまでは，大 体に扣いて受胎は素朴的に自然のままに放任 されていた，その基底には産児を家運繁昌の もととして無条件に喜ぶ風潮が民族に固定し ており，受胎調節は「よからぬこと」という国 民感情があつた。

大正期に至つて 禁欲または機械的あるいは 楽物による方法で受胎調節をすることを必ず しも罪悪と感じないような考え方が広まり始 めた．それは一方では合理主義精神の淩透が ありまた需教的教条主義を裹てて人間性を 尊重するというとユーマニズムの精神が萠え 出て来たことに相当している. しかし，それ にしても大正11年のマーガレット・サンガー夫 人の来日は大きな制湤となつた。

大正から昭和に入る頃になると受胎調節の 思想は簐部の唱尊した彭張主義の下では全く のタブーであり, 世は「産めよ殖兄よ」の声に 埋まつた。この条件は終戦とともに解消した ばかりでなく, 人口過剩の悩みが政治の根本 をゆるがせた。

この人口圧力に対する一般民衆の反応とし て急速に受胎調節が普及した。しかし，それ と同時に人工妊娠中絶が著しく增加した。こ のことは社会心理学的に見れば, 中下層社会 に拈いては，さもあり得べきこととして理解 される.すなわち受胎調節, 或いはさらに進 んで家族計画となると,それは計画的な事前措 置の生活態度であるが, そのような未来までも 一緒に考える生活態度になじまず,むしろ結果 を見て初めて事の意味を理解し, 事後救済に頼 るという下民的生活の姿㪄が，この場合にも 現われたものとして理解しなければならない。 受胎調節の基礎にある考劣方は，明確に反 省認識するとき，家族計画と呼ばれる，それ は子を持つことを計画的に考克，かつ行なう
といら意味である. 正しい家族計画の唱導が 熱心に推し進められるにも拘らず，隻生保護 法を「隐れみの」にして不当の人工妊娠中絶が 横行している傾向が，乙ばしば指摘され，識 者の娙虑する所となつている，著者はその概 要を総説し，また母体に与皇た和とるべき後 遗症の 3 例を引用した。

これらの悪の根元は，どこに求めるべきあ るか?.その答えは簡単でない，何となれば原 因には構造があり，詳細な調査検討なしには 原因を云々することはできないからである。 本稿に和いては著者は, 現行の態生保護法の 不備といら一点に問題を絞り，原因の重要な 一環として，世の注意を喚起した。一番の要 点は, クライェントと優生指定医とだけの合 意さ光あれば，ほしいままに人工妊娠中絶手 術が実施できるということにある。法文は一 忘, 倫理性をみたしているにしても, 奏際上, 蔴胎を抑止できないという意味ではザル法で ある.このような，結果に打いて堕胎の自由 を許すような法律は，日本人の法意識も倫理 意識も低落に 導びくことになる，法の最初の 意図はともかく，この法律は今や悪法となつ ていると云われなければならない，国民の身 体的問題及び物質的生活支援の問題とともに, 精神的, 倫理的バックボーン確立の問題が極 めて重要であることを思えば，速やかにこの 法を改正して，その有害要絜を取り除くべき であると考党る。

\section{参考 資 料}

1. 石垣純二：特集，陮胎天国日本，優生保变法 批判, 婦人公論 7,240 (昭36)

2. 昭和 23 年 7 月, 法符 156 号

3. 昭和36年厚生の指標, 人口動態統計, 厚生統 計協会 (昭36)

4. 高口保明: 家族計画便覧（昭36年度版）

5, 古屋芳雄：1957年你日新開, 人口問題調查会

6. 村松稔：管族部西ハンドバッグ,69, 日本家族 洲西普及会 (昭32)

7. 遠藤ユリ子, 高橋美子: 私の中紿休䮖, 邚人公 論, 7, 252 (昭36)

8. 家族計画ニニース：昭 36 年 8 月号, No.89 (昭36年) 